He, Kai and Steve Chan. 2018. "Thinking about Change: American Theorizing and

Chinese Reasoning on World Politics," International Studies Review 20 (2): 326-333

\title{
Thinking about Change: American Theorizing and Chinese Reasoning on World Politics
}

\author{
Kai He and Steve Chan
}

\section{Introduction}

This essay addresses conceptions of change in two contemporary and influential US theories of international relations and their resonance with Chinese predilections in thinking about and coping with change. We focus on prevailing Chinese views on structural change in world politics, views that reflect both traditional culture and Marxist socialization. We compare them with the views on change presented by the power-transition theory (Organski and Kugler 1980; Gilpin 1981; Tammen et al. 2000) and the leadership long-cycle theory (or the transition/leadership model: Modelski 1987; Modelski and Thompson 1996; Thompson 2009; Rapkin and Thompson 2013), thereby treating these well-known theories as representatives of Western (or at least US) ways of thinking about change. Naturally, we can only speak about certain proclivities or central tendencies as cultural traditions are hardly monolithic. We seek to show both convergences and distinctions between American IR theorizing and Chinese understanding about international structural transformation. We thus intend to move away from the tendency by some Sinologists to only stress Chinese "uniqueness", so that we can bridge the intellectual gap between the US and China in understanding change in world politics.

We first examine three key questions concerning change in world politics: (1) who is the key agent of change? (2) why does change take place? And (3) how does change happen in history? Then we focus on the bimodal feature of Chinese strategic thinking on how to shape 
change in world politics by briefly examining some highlights of Chinese foreign policy from Mao and Deng to Xi. We suggest that Chinese leaders respond to pressures stemming from both their domestic and international environment. They tend to be more risk-acceptant when facing a deteriorating situation and more inclined to pursue a moderate approach when facing a benign environment.

\section{Convergences and Divergences: Who, Why, and How}

One of the fundamental questions characterizing people's thinking about change pertains to the role of structure and agency. Although some American IR theories emphasize human agency, the two theories we have selected for attention in this paper focus on the influence of international structure. Power-transition theory and leadership long-cycle theory give analytic priority to the nature of circumstances in which leaders find themselves rather than to their personal volition or motivation. Despite its structural orientation, power-transition theory clearly attaches importance to what a country does with its endowments, such as when it argues that economic development and policy capacity can enable a smaller country to prevail over a larger one (Organski and Kugler 1980; Tammen et al. 2000). Similarly, the leadership long-cycle theory stresses that physical size does not necessarily confer an advantage in global positional competition. Those countries that have reached the pinnacle of the international relations hierarchy are more nimble and adaptable; their entrepreneurial élan and capacity for technological innovation are the fundamental reasons for their greatness (Modelski 1987; Modelski and Thompson 1996; Thompson 2009; Rapkin and Thompson 2013). Therefore, the agency of change in powertransition and leadership long-cycle theories refers to the state or country. 
Differing from the American structure-oriented approach, Chinese thinking gives more emphasis to agency in changing international politics. Influenced by Marxist thinking, Chinese leaders accept the axiom that objective material conditions shape human thought and behavior and thus determine the limits of policy feasibility. However, this belief is balanced by the view that human thought holds the key to transform the material world and can indeed prevail over objective conditions. Mao Tse-tung's oft-remarked comments about the power of people's revolutionary spirit (such as in overcoming technological inferiority including nuclear weapons) argue that change is rooted in the agency of human beings, not states or countries. Mao is also remembered for telling the story about the (perceived) silly old man who wanted to remove a mountain by the dint of his own and his descendants' effort (愚公移山), thus emphasizing the importance of effort mobilization and perseverance in overcoming long odds (Bobrow et al. 1979; 1984). Moreover, the Chinese emphasis on human agency acknowledges the possibility of disappointing setbacks in the short run while maintaining confidence in the long haul ("one shouldn't worry about running out of firewood if the mountain continues to sustain forestry," 留得青山在, 不怕没柴烧). This long-term confidence, even in the face of a recent devastating defeat, is captured by the Marxist view that "The setbacks, failures, and deaths of socialism are temporary phenomena, and it will be able to recover quickly. Even in case of total failure, the setbacks are temporary and could be recovered" (Mao Tse-tung quoted in Worker-PeasantSoldier Team 1971, 84).

A second and obviously critical issue in regard to thinking about change pertains to its sources. What are the drivers of change? Both US theories discussed here and Chinese thinking emphasize internal sources of change. As international relations analysts, we are all perhaps disposed to direct attention to a country's external circumstances. Power-transition and 
leadership long-cycle theories, however, are quite definite that conditions internal to a country will be decisive in determining its position in the world. Thus, for example, the Phoenix phenomenon shows that even a devastating defeat in war cannot bend a country's growth trajectory after a relatively short interlude - demonstrated by the rapid economic recovery of Japan and Germany after World War II. Similarly, according to the leadership long-cycle theory, differences in human capital and institutional adaptability in advancing the technological frontier and developing leading economic sectors constitute the fundamental drivers of global power shifts among countries.

Chinese thinking on change also concurs with the primacy of internal factors in producing positive or negative change. For instance, domestic chaos or weakness is seen to be the leading cause for setbacks in foreign policy. A country's external success depends on its domestic performance. One implication of this line of reasoning is that much of what preoccupies foreign policy analysts, such as arguments about the balance of power and alliance making (e.g., whether to contain or engage China), tends to be secondary to international positional competition. Domestic conditions and performance are ultimately more decisive.

Marxist dialectics of course sees history unfolding in stages (e.g., from feudalism to capitalism to socialism). Chinese discourse on political economy and warfare also often refers to stages or phases, such as when a civil war moves from guerrilla warfare to conventional or positional warfare, and when an economy manages to take off and subsequently gains cruising altitude. We can discern similar views in the two US structural theories taken up in this paper. For instance, the power-transition theory talks about the period leading to approximate parity and the period during or after overtaking. Similarly, the leadership long-cycle theory delineates 
phases of power concentration and de-concentration. They both offer hypotheses about the different probability of conflict occurrence during these phases.

Both Chinese traditional thinking and Marxist logic emphasize the need to distinguish between quantitative and qualitative change. Quantitative change suggests incremental revisions that do not alter the basic relationship between actors. Qualitative change, however, augurs a fundamental revision in this relationship. In Mao Tse-tung's words (quoted in the Tientsin Writing Group 1975, 87, 90),

Change in all things takes two forms: the form of [apparent] opposing stagnation and the form of manifest change... When things are in the first form, there is only quantitative change and no qualitative change and, therefore, they give the appearance of stagnation. When things are in the second form, the quantitative change in the first form has reached a certain high point, causing the breakup of the unified existence [of their elements] and creating qualitative change... Things are constantly changing from the first form to the second form. The struggles between contradictions take place in both of these forms, but the resolutions of contradictions are reached through the second form.

Naturally, this distinction is also present in the two American structural theories we discuss here and, indeed, in other types of analysis. For example, a process of gradual decline of US relative power can occur within a unipolar system still dominated by it - one that has prevailed since the USSR's demise, concluding the Cold War (Thompson 2017). A process of bipolarization can take place within a unipolar system such as when China closes the capability gap separating it from the US. What is critical here is the distinction between within-system (quantitative) change and between-system (qualitative) change, such as when a process of bipolarization eventually moves international relations from a unipolar system to a bipolar system.

Implicit in the above discussion, and especially as emphasized by Mao's quote above, is the idea that change in the Chinese view can involve long gestation periods of incremental (quantitative) change producing eventually sudden spurts of (qualitative) transformation. There 
can therefore be long periods of apparent stagnation even while secular trends are creating cumulative change under the surface (冰冻三尺, 非一日之寒). This process provides the relevant circumstances whereby a catalyst can trigger a major transformation of the system (星星之火, 可以燎原). William Thompson's (2003) analysis on the genesis of World War I captures this view of history (such as the chain of events set off by the assassination of AustriaHungary's archduke in Sarajevo). The views just presented correspond to the theory of punctuated equilibrium (e.g., Hu 2012) which has been applied by paleontologists to the study of evolution.

Last, but not least, how do historical changes unfold? Here again we observe both convergences and divergences between the two American IR theories and Chinese thinking. While both emphasize the inevitability of structural change in world politics, they hold different views on the tendency or path of change. Power-transition theory appears quite clear in predicting that, in the long run, demographic size will determine a country's relative international position. Because it focuses on national power in the industrial era, it privileges hard power (including population which, in its view, will ultimately trump all other factors) over soft power (including the power of knowledge and technology). This theory appears to present a more linear progression of history. In this respect, it shares with Marxism a linear and progressive view of history. In contrast, the leadership long-cycle theory calls attention to repeated patterns in the form of cycles of power concentration and de-concentration and also of alternating phases of legitimization and de-legitimization of the reigning hegemon's world order.

Chinese discourse claims both the long-term inevitability of historical developments (such as the eventual culmination of a communist utopia in Marxist thinking) and also a cyclical view of politics (such as the proposition that unification inevitably leads to fragmentation and 
fragmentation regularly returns to unification; 合久必分, 分久必合). This discourse therefore shares some features with the two US theories, such as their respective views on the inevitable rise of countries with large populations and the cyclical repetition of power concentration and deconcentration. The Chinese/Marxist dialectical view of history as a series of contradictions and their successive resolutions is captured by Mao's statement (quoted in Worker-Peasant-Soldier Team 1971, 8): "Contradictions [meaning the struggle of opposing forces] take place constantly and are resolved constantly; this is the dialectical law of material development". This combination promotes confidence in the long run but also urges attention to learn from and make anticipatory preparations for inevitable changes.

\section{China's Bimodal Approach to Change in Practice}

One unanswered question, however, is about strategy, for example, how to promote positive change in practice. In this and other respects (Bobrow et al. 1979), Chinese thinking features a duality or a bimodal approach to risk taking. On the one hand, one is counseled against precipitous action before circumstances have ripened. Caution is urged (one needs to engage in deep reflection before taking action; 三思而后行), and officials are advised to take a long-term view and to refrain from actions that would force a premature confrontation. Sometimes, a waitand-see attitude (that haste can cause failure, 欲速则不达), as well as passivity and inaction, can be a superior course of action compared to hyper activity (无为而治; 静以修身). On the other hand, officials are urged to be vigilant and engage in constant anticipatory preparation (未雨綢繆; meaning literally to "make preparations before rain arrives") in order to seize any opportunity that presents itself (机不可失, 时不再来; meaning that an opportunity will not present itself again). Moreover, at the right time, Chinese strategic thinking also advocates risk- 
acceptant behavior because “nothing ventured, nothing gained” (不入虎穴，焉得虎子: meaning literally, "How do you catch the tiger cub without entering the tiger's lair?"). Here, the bimodal approach refers to the two seemingly contradictory and yet complementary strategies: restraint, and risk-taking. Ideally, readiness or preparation plays a bridging role in connecting these two strategies because readiness is the outcome of strategic restraint and also the precondition for taking risks.

In practice, Chinese foreign policy is shaped by a contestation between these two strategic thoughts. When China faces a deteriorating environment, Chinese leaders, like Mao, are more likely to be inclined to take risks in managing change. For example, Mao entered the Korean War because he believed that US involvement in the Peninsula targeted the newly established People's Republic (Whiting 1960). External pressure was thus linked to threats to internal control. China's risk-taking behavior was motivated by a sense of vulnerability and an attempt to arrest or reverse a trend that, in its leaders' view, would cause even greater harm if they had not acted (e.g., Christensen 2006).

In the same vein, the 1995-96 Taiwan missile crisis took place when Chinese leaders, especially Jiang Zemin, felt betrayed by the Clinton Administration that had previously promised Beijing that it would not allow Taiwan President Lee Teng-hui to visit the United States. When the US State Department issued a visa to Lee and thereby broke its promise to Beijing, it produced a psychological shock that put Chinese leaders in a domain of losses even though this episode is obviously different from the outbreak of the Korean War. Jiang, therefore, chose a risk-taking policy by escalating tension across the Taiwan Strait in 1995-96 (Christopher 1998; Qian 2006; Hall 2011; He and Feng, 2013; He 2016), hoping to reverse a disadvantageous situation. 
Chinese leaders have also sometimes acted in the opposite manner. The prudent and cautious trend in Chinese thinking regarding change has characterized Beijing's low profile after the Cultural Revolution. This orientation, led by Deng Xiaoping, featured the slogan "never seeking hegemony, never seeking leadership" (不争霸, 不当头) and “biding one's time and hiding one's 'brilliance”” (蹈光养晦) (Deng 1984). During this period, China faced a relatively relaxed external environment. Nixon's historical visit in 1972 led to a "tacit alliance" between China and the United States against the Soviet Union during the Cold War. Military cooperation with the United States significantly alleviated strategic pressures on China. Deng's dominance of domestic politics also encouraged a policy of economic reform, although political relaxation was reversed after the Tiananmen Square crackdown in 1989.

Although this incident seriously strained relations with the West, China soon broke its international isolation by deepening its economic engagement with the outside world. The collapse of the Soviet Union, to a certain extent, eliminated the only threat to China's territorial security and thereby created the best external security environment since the People's Republic was established in 1949. This development was also accompanied by greater domestic stability and elite control.

From Jiang to Hu Jintao, China basically followed Deng's policy guidance to adopt a low-profile foreign policy toward the United States and conduct a good-neighbor policy in the region. Although there were some foreign policy crises, such as the 1995-96 Taiwan crisis, the 1999 Embassy Bombing incident, and the 2001 EP-3 midair collision, Chinese foreign policy has been risk-averse in the 1990s and the first decade of the 2000s. In order to alleviate the threat perception of other countries, China even changed its policy slogan of "peaceful rise" to "peaceful development" in 2004 because Chinese elites believed that the word "rise" might 
cause suspicions and apprehensions from others (Glaser and Medeiros 2007). Consequently, we have witnessed China's charm offensive toward Southeast Asia, Africa, and Latin America in the first two decades after the Cold War (Kurlantzick 2007).

Since the 2008 global financial crisis, however, China's foreign policy has turned to a more "assertive" direction according to some outside observers. For example, China's land reclamation in the South China Sea has worried its neighboring states as well as the United States. There are several competing explanations of this apparent change in Chinese diplomacy (He and Feng 2012; Johnston 2013). For example, Chinese scholars point to the US pivot or rebalance as the driving force behind the diplomatic flare-ups in the South China Sea (Fu and $\mathrm{Wu}$ 2016). Other scholars, however, suggest that China's assertiveness is rooted in domestic legitimacy and nationalism (Ross 2012) and that the US pivot is not the cause but a reaction to China's policy change (Lieberthal 2011; Manyin et al. 2012). Due to space limitation, we cannot discuss in detail these alternative interpretations.

However, one undeniable fact is that the US pivot or rebalancing was seen by Beijing as an effort to contain China after the 2008 financial crisis (Liberthal and Wang 2012; Yan 2013). Therefore, it is possible that the US pivot and China's assertiveness have reinforced each other and led to strained bilateral relations between the two nations. Naturally, one can debate about whether a more assertive foreign policy is necessarily a more risk-acceptant policy because in the face of a more politically engaged public, perceived passivity or ineffectiveness in Beijing's foreign policy can also be risky for reasons of domestic politics.

\section{Conclusion}


In this paper, we highlight some features of Chinese strategic thinking about change and the perspectives offered by two US theories about change in world politics. We argue that Chinese views correspond in some respects with the power-transition theory and the leadership longcycle theory but tend to also be more distinctive (if only in relative emphasis) in other respects. Moreover, we show that Chinese views can consist of prognoses and injunctions that present seeming contradictions and can be sources of analytic tension. For instance, analysts are told to be vigilant about short-term setbacks while remaining confident about long-term success (or to acknowledge the constraints of material conditions on policy feasibility while recognizing the importance of human spirit).

By briefly examining China's foreign policy orientation from Mao to Deng as well as the recent "assertive turn" in diplomacy under Xi Jinping, we suggest that Chinese views are not fixed but rather respond to the environment (both domestic and foreign). This adaptation sometimes encourages risk taking and on other occasions urges moderation and caution. Other factors, such as leadership, domestic politics, and international power structure, will matter for Chinese foreign policy. Naturally, as Thomas Christensen (2015) argues, external actors, especially the United States, will also play an important role in shaping China's choices.

\section{References}

Bobrow, Davis B., John A. Kringen, And Steve Chan. 1984. "Change and the Chinese.” In Images and Reality in International Politics, edited by Nissan Oren, 81-94. New York: St. Martin's Press.

Bobrow, Davis B., Steve Chan, And John A. Kringen. 1979. Understanding Foreign Policy Decisions. New York: Free Press. 
Christensen, Thomas J. 2015. The China Challenge: Shaping the Choices of a Rising Power. New York: Norton.

Christensen, Thomas J. 2006. "Windows and War: Trend Analysis and Beijing's Use of Force." In New Directions in the Study of China's Foreign Policy, edited by Alastair I. Johnston and Robert S. Ross, 50-85. Stanford: Stanford University Press.

Christopher, WARren. 1998. In the Stream of History: Shaping Foreign Policy for a New Era. Stanford: Stanford University Press.

Deng, Xiaoping. 1984. Selected Works of Deng Xiaoping, 1975-1982 (Vol. 2). Beijing: China Books \& Periodicals.

Fu, Ying AND Wu Shicun. 2016. "South China Sea: How We Got to This Stage." The National Interest, May 9, http://nationalinterest.org/feature/south-china-sea-how-we-got-stage16118.

GilPin, Robert. 1981. War and Change in World Politics. Cambridge: Cambridge University Press.

Glaser, Bonnie S. And Evan Medeiros. 2007. "The Changing Ecology of Foreign PolicyMaking in China: The Ascension and Demise of the Theory of 'Peaceful Rise." China Quarterly 190: 291-310.

HaLl, TodD H. 2011. "We Will Not Swallow This Bitter Fruit: Theorizing a Diplomacy of Anger." Security Studies 20(4): 521-555.

HE, KAI. 2016. China's Crisis Behavior. Cambridge: Cambridge University Press.

He, Kai And Huiyun Feng. 2013. Prospect Theory and Foreign Policy Analysis in the Asia Pacific: Rational Leaders and Risky Behavior. London: Routledge. 
He, Kai And Huiyun Feng. 2012. “Debating China’s Assertiveness: Taking China's Power and Interests Seriously.” International Politics 49(5): 633-644.

Hu, WeIXING. 2012. "Explaining Change and Stability in Cross-Strait Relations: A Punctuated Equilibrium Model.” Journal of Contemporary China 21(78): 933-953.

Johnston, Alastair IAIN. 2013. "How New and Assertive is China's New Assertiveness?" International Security 37(4): 7-48.

Kugler, JaceK And Douglas Lemke, eds. 1996. Parity and War: Evaluations and Extensions of The War Ledger. Ann Arbor: University of Michigan Press.

Kurlantzick, Joshua. 2007. Charm Offensive: How China's Soft Power Is Transforming the World. New Haven: Yale University Press

LEVY, JACK S. 2008. "Power Transition Theory and the Rise of China." In China's Ascent: Power, Security, and the Future of International Politics, edited by Robert S. Ross and Zhu Feng, 11-33. Ithaca: Cornell University Press.

LeVy, Jack S. And William R. Thompson. 2010. "Balancing on Land and at Sea: Do States Ally Against the Leading Global Power?” International Security 35(1): 7-43.

LeVy, Jack S. And William R. ThOmPson. 2005. "Hegemonic Threats and Great-Power Balancing in Europe, 1495-1999." Security Studies 14(1): 1-33.

Lieberthal, Kenneth. 2011. “The American Pivot to Asia.” Foreign Policy 21: 20-35.

Lieberthal, Kenneth And Wang Jisi. 2012. Addressing US China Distrust. Washington, DC: Brookings Institution.

Manyin, M.E., S. Daggett, B. Dolven, S.V. Lawrence, M.F. Martin, R. O’Rourke and B. Vaughn. 2012. "Pivot to the Pacific? The Obama Administration's Rebalancing Toward Asia.” Library of Congress. Washington, DC: Congressional Research Service. 
Modelski, GeOrge And William R. ThOMPSON. 1996. Leading Sectors and World Power: The Coevolution of Global Politics and World Economics. Columbia: University of South Carolina Press.

Modelski, George. 1987. Long Cycles in World Politics. London: Macmillian.

Organski, A.F.K. AND JACEK KugleR. 1980. The War Ledger. Chicago: University of Chicago Press.

QIAN, QICHEN. 2006. Ten Episodes in China's Diplomacy. London: Harper Collins.

Rapkin. David P. AND William R. Thompson. 2013. Transition Scenarios: China and the United States in the Twenty-First Century. Chicago: University of Chicago Press.

Ross, Robert. 2012. “The Problem with the Pivot: Obama's New Asia policy is Unnecessary and Counterproductive." Foreign Affairs 91(6): 70-82.

Tammen, Ronald L., Jacek Kugler, Douglas Lemke, Allan C. Stam III, Mark Abdollahian, Carole Alsharabati, Brian Efird, and A.F.K. Organski. 2000. Power Transitions: Strategies for the $21^{\text {st }}$ Century. New York: Chatham House.

Thompson, William R. 2017. “The Problem with Unipolarity.” Paper presented at the annual meeting of International Studies Association, Baltimore.

Thompson, William R. 2009. "Structural Preludes to Systemic Transitions since 1494." In Systemic Transitions: Past, Present and Future, edited by William R. Thompson, 55-73. New York: Palgrave Macmillan.

Thompson, William R. 2003. “A Streetcar Named Sarajevo: Catalysts, Multiple Causation Chains, and Rivalry Structures." International Studies Quarterly 47(3): 453-74.

Tientsin Writing GrouP. 1975. Talks on Dialectical Materialism. Peking: People's Publishing House. 
Whiting, Allen. 1960. China Crosses the Yalu: The Decision to Enter the Korean War. Stanford: Stanford University Press.

Worker-Peasant-Soldier Team of the Central Party School for Studying Philosophy. 1971. Thoroughly Study Marxist Theory of Knowledge. Peking: People's Publishing House.

Yan, Xuetong. 2014. "From Keeping a Low Profile to Striving for Achievement." Chinese Journal of International Politics 7(2): 153-184.

Yan, Xuetong. 2013. "Strategic Cooperation without Mutual Trust: A Path forward for China and the United States." Asia Policy 15(1): 4-6. 